\title{
HUBUNGAN ANTARA PERILAKU IBU TENTANG PEMBERIAN SUSU FORMULA DENGAN STATUS GIZI BALITA USIA 6-24 BULAN
}

\author{
Arling Tamar Daworis ${ }^{*}$, Ari Damayanti Wahyuningrum ${ }^{2 *}$, Ika Arum Dewi ${ }^{3}$ \\ 1, 2,3 STIKES Widyagama Husada Malang
}

*Corresponding author:
Ari Damayanti Wahyuningrum
STIKES Widyagama Husada Malang
Email: damayantiari1982@gmail.com

\begin{abstract}
Nutrition for infants and toddlers will affect nutritional status. Nutritional status of less or more will determine the degree of health, growth and development of toddlers. Good nutrition for infants and toddlers will affect nutritional status. Nutritional status is one indicator of the success of development. The state of malnutrition, especially in toddlers, will result in disruption of physical growth and intelligence. One of the efforts in optimizing the growth and development of children is the provision of formula milk. The purpose of this study was to determine the relationship between the mother's behavior regarding formula feeding and the nutritional status of children aged 6-24 months at the Posyandu, Dinoyo Village, Malang City. This research method uses a quantitative method with a correlative approach which is carried out on 60 respondents of mothers with toddlers aged 6-24 months at the Posyandu, Dinoyo Village, Malang City.This research method uses a quantitative method with a correlative approach which is carried out on 60 respondents of mothers with toddlers aged 6-24 months at the Posyandu, Dinoyo Village, Malang City. The data collection technique was carried out by providing research instruments in the form of a mother's behavior questionnaire about formula feeding and the results of measuring the nutritional status of toddlers aged 6-24 months which were then tested using SPSS with the Spearman Rank correlation test. The results of this study indicate that there is a significant relationship between mother's behavior regarding formula feeding and nutritional status in toddlers aged 6-24 months, who visited the Posyandu in Dinoyo Village, Malang City $(\square$ vakue $=0.000)$. Of the 60 respondents, almost half the number of mothers with toddlers aged 6-24 months who visited the Posyandu in the Dinoyo Sub-District, Malang City, behaved appropriately and most of the mothers with children aged 6-24 months who visited the Posyandu in the Dinoyo Sub-District, Malang City, had good nutritional status. . It can be concluded that the more precise mothers behave about formula feeding, the better nutritional status for toddlers aged 6-24 months, especially those who visit the Posyandu, Dinoyo Village, Malang City.
\end{abstract}

Keywords: Mother's behavior, formula milk, nutritional status, toddlers aged 6-24 months.

\begin{abstract}
Abstrak
Pemberian nutrisi pada bayi dan balita yang baik akan mempengaruhi status gizi. Status gizi kurang atau lebih akan menentukan derajat kesehatan, pertumbuhan dan perkembangan balita. Pemberian nutrisi pada bayi dan balita yang baik akan mempengaruhi status gizi. Status gizi merupakan salah satu indikator keberhasilan pembangunan. Keadaan kurang gizi terutama pada balita akan mengakibatkan terganggunya pertumbuhan fisik dan kecerdasan. Salah satu upaya dalam mengoptimalkan pertumbuhan dan perkembangan anak adalah pemberian susu formula. Tujuan dari penelitian ini adalah Mengetahui adanya hubungan antara perilaku Ibu tentang pemberian susu formula dengan status gizi balita usia 6-24 bulan di Posyandu Wilayah Kelurahan Dinoyo Kota Malang. Metode penelitian ini menggunakan metode kuantitatif dengan pendekatan korelatif yang dilakukan pada 60 responden ibu dengan balita usia 6-24 bulan di Posyandu Wilayah Kelurahan Dinoyo Kota Malang. Teknik pengumpulan data dilakukan dengan cara memberikan instrumen penelitian berupa kuesioner perilaku Ibu tentang pemberian susu formula dan hasil pengukuran status gizi balita usia 6-24 bulan yang kemudian di uji menggunakan SPSS dengan uji korelasi Rank Spearman. Hasil penelitian ini menunjukkan terdapat hubungan signifikan antara perilaku Ibu tentang pemberian susu formula dengan berstatus gizi pada balita usia 6-24 bulan, yang berkunjung ke Posyandu Wilayah Kelurahan Dinoyo Kota Malang $\left(\rho_{\text {vakue }}=0,000\right)$. Dari 60 responden, hampir setengah jumlah Ibu dengan balita usia 6-24 bulan yang berkunjung ke Posyandu Wilayah Kelurahan Dinoyo Kota Malang berperilaku tepat dan sebagian besar jumlah Ibu dengan balita usia 6-24 bulan yang berkunjung ke Posyandu Wilayah Kelurahan Dinoyo Kota Malang berstatus gizi baik. Dapat disimpulkan bahwa semakin tepat Ibu dalam berperilaku tentang pemberian susu formula maka dapat meningkatkan berstatus gizi baik pada balita usia 6-24 bulan, khususnya yang berkunjung ke Posyandu Wilayah Kelurahan Dinoyo Kota Malang.
\end{abstract}

Kata Kunci: perilaku Ibu, susu formula, status gizi, balita usia 6-24 bulan. 


\section{PENDAHULUAN}

Balita merupakan kelompok masyarakat yang rentan gizi. Masalah gizi pada anak masih menjadi masalah di beberapa negara. Tercatat 1 dari 3 anak di dunia meninggal setiap tahun akibat buruknya kualitas gizi. Salah satu riset menunjukkan setidaknya 3,5 juta anak meninggal setiap tahun karena masalah kekurangan gizi dan buruknya kualitas makanan, didukung pula oleh kekurangan gizi selama masih di dalam kandungan. Pada kelompok tersebut mengalami siklus pertumbuhan dan perkembangan yang membutuhkan zat-zat gizi yang lebih besar dari kelompok umur yang lain sehingga balita paling mudah menderita kelainan gizi. Pemberian nutrisi pada bayi dan balita yang baik akan mempengaruhi status gizi. Status gizi kurang atau lebih akan menentukan derajat kesehatan, pertumbuhan dan perkembangan balita. Persoalan gizi ini juga merupakan salah satu persoalan utama dari pembangunan manusia di Indonesia. Sebagai salah satu negara dengan kompleksitas kependudukan yang sangat beraneka ragam, Indonesia dihadapioleh dinamika persoalan gizi buruk (Aries \& Martianto, 2006 dalam Saputra \& Nurrizka, 2013). Masalah kurang gizi masih menjadi masalah kesehatan masyarakat dan dapat menjadi penyebab kematian terutama pada kelompok resiko tinggi yaitu bayi dan balita (Depkes RI, 2006 dalam Mahaling, 2013).

Masalah gizi di Indonesia saat ini memasuki masalah gizi ganda (double burden). Artinya, masalah gizi kurang (Underweight) belum teratasi sepenuhnya, sementara muncul masalah gizi lebih (Overweight). Kejadian Overweight terus mengalami peningkatan dari tahun ke tahun baik pada kelompok anak-anak maupun dewasa (Kemenkes RI, 2016). Menurut WHO yang dikutip dalam Roesli (2008), susu formula adalah susu yang sesuai dan bisa diterima sistem tubuh bayi. Susu formula yang baik tidak menimbulkan gangguan saluran cerna seperti diare, muntah atau kesulitan buang air besar.

\section{METODE}

Desain penelitian yang digunakan dalam penelitian ini adalah kuantitatif dengan pendekatan cross-sectional survey, dimana antara kedua variabel dikaji dan dianalisis dalam satu waktu. Subjek yang digunakan yaitu Ibu dengan balita usia 6-24 bulan yang berkunjung ke posyandu wilayah Kelurahan Dinoyo Kota Malang, pengambilan sampel pada penelitian ini dilakukan menggunakan teknik purposive sampling yaitu memilih Ibu yang memiliki balita usia 6-24 bulan sesuai dengan kriteria inklusi. Variabel dalam penelitian ini adalah perilaku Ibu tentang pemberian susu formula dan status gizi pada balita usia 6-24 bulan. Penelitian dilakukan selama bulan Juni 2021 yang bertempat di posyandu wilayah Kelurahan Dinoyo Kota Malang. Teknik pengumpulan data dilakukan dengan cara memberikan instrumen penelitian berupa kuesioner perilaku Ibu tentang pemberian susu formula menggunakan kuesioner dan hasil pengukuran status gizi balita usia 6-24 bulan. Penelitian ini tidak memberikan intervensi dan hanya membagikan kuesioner pada responden. Analisis data yang digunakan yaitu analisa univariat dan bivariat. Analisis data bivariat yang digunakan adalah uji korelasi Rank Spearman.

\section{HASIL DAN PEMBAHASAN}

Karakteristik Ibu dengan balita usia 6-24 bulan sebagai responden meliputi:

Tabel 1. Karakteristik Demografi Ibu

\section{Variabel}

Jumlah Prosentase

(n)

(\%)

Usia

35

58,3

25-30 tahun

17

28,4

31-35 tahun

8

13,3

36-40 tahun

\section{Pendapatan}




$\begin{array}{lcc}\text { Rp. 1.000.000-Rp. 2.000.000 } & 32 & \text { 53,3 } \\ \text { Rp. 2.000.000-Rp. 3.000.000 } & 28 & 46,7 \\ \text { Pendidikan } & & \\ \text { SMP } & 4 & 6,7 \\ \text { SMA } & 38 & 63,3 \\ \text { DIII } & 8 & 13,3 \\ \text { S-1 } & 10 & 16,7\end{array}$

\section{Pekerjaan}

IRT

PNS

Pengawai Swasta

Wiraswasta/Berdagang,

Bertani/Berkebun

\section{Jumlah Anggota Keluarga}

2-3 orang

$>3$ orang

Jenis Kelamin Balita

Laki-laki

Perempuan

30

50

\section{Urutan Balita Sebagai}

\section{Anak Dalam Keluarga}

Ke-1

Ke-2 dan setelahnya

\section{7}

\section{3}

\section{,7}


susu formula $\left(\rho_{\text {value }}=0,014<0,05\right)$ artinya Ibu yang bekerja mempunyai waktu kerja sama seperti dengan pekerjaan lainnya. Adapun waktu kerja bagi pekerja yang waktu siang 7 jam satu hari dan 40 jam satu minggu untuk 6 hari kerja dalam satu minggu, atau 8 jam satu hari dan 40 jam satu minggu. Sisa waktunya 16-18 jam dipergunakan untuk kehidupan dalam keluarga, masyarakat, tidur dan lain-lain (Desi, 2010). Bagi pekerja wanita, bagaimanapun juga mereka adalah ibu rumah tangga yang sulit lepas begitu saja dari lingkungan keluarga. Wanita mempunyai beban dan hambatan lebih berat dibandingkan rekan prianya. Dalam arti wanita harus lebih dulu mengatasi urusan keluarga, suami, anak, dan haal-hal yang menyangkut kebutuhan rumah tangga.

Berdasarkan pendapatan Ibu menunjukkan sebagian besar responden dengan pendapatan sebesar Rp. 1.000.000-2.000.000 sebanyak 32 orang (53,3\%). Jumlah pendapatan Ibu Kota Malang ini juga mendukung teori dari Supariasa (2010) bahwa faktor yang berpengaruh terhadap status gizi antara lain faktor langsung berupa konsumsi makan bahwa pengukuran konsumsi makan sangat penting untuk mengetahui kenyataan apa yang dimakan oleh masyarakat dan hal ini dapat berguna untuk mengukur status gizi dan menemukan faktor diet yang dapat menyebabkan malnutrisi dan faktor tidak langsung berupa pengaruh budaya dengan sikap terhadap makanan dan pola pemberian makanan dan dan dapat terpenuhinya faktor pola asuh keluarga bahwa pola pendidikan yang diberikan orang tua kepada anak-anaknya. Hasil ini sejalan hasil penelitian oleh Fitri (2013) menyatakan bahwa ada hubungan yang bermakna antara sosial ekonomi dengan perilaku pemberian susu formula ( $\rho_{\text {value }}$ $=0,043<0,05)$.

Berdasarkan jumlah anggota keluarga Ibu bahwa sebagian besar responden memiliki $2-3$ orang anggota keluarga sebanyak 45 orang (75\%). Keluarga merupakan unit terkecil dari masyarakat yang terdiri dari kepala keluarga dan anggota keluarga lainnya yang berkumpul dan tinggal dalam suatu rumah tangga karena pertalian darah dan ikatan perkawinan atau suatu adopsi. Antara satu keluarga dengan keluarga lainnya saling bergantung dan berinteraksi. Bila salah satu atau beberapa anggota keluarga tersebut mempunyai masalah kesehatan, maka akan berpengaruh terhadap anggota keluarga lainnya serta keluarga lain yang ada disekitarnya (Mubarak, 2009).

Berdasarkan urutan balita usia 6-24 bulan sebagai anak dalam keluarga bahwa sebagian besar balita usia 6-24 bulan adalah anak ke-1 sebanyak 48 balita $(80 \%)$. Keluarga merupakan unit terkecil dari masyarakat yang terdiri dari kepala keluarga dan anggota keluarga lainnya yang berkumpul dan tinggal dalam suatu rumah tangga karena pertalian darah dan ikatan perkawinan atau suatu adopsi. Antara satu keluarga dengan keluarga lainnya saling bergantung dan berinteraksi. Bila salah satu atau beberapa anggota keluarga tersebut mempunyai masalah kesehatan, maka akan berpengaruh terhadap anggota keluarga lainnya serta keluarga lain yang ada disekitarnya (Mubarak, 2009).

\section{Tabel 2. Perilaku Ibu Tentang Pemberian Susu} Formula

\begin{tabular}{lcc}
\hline Kategori & $\begin{array}{c}\text { Jumlah } \\
(\mathbf{n})\end{array}$ & $\begin{array}{c}\text { Prosentase } \\
(\boldsymbol{\%})\end{array}$ \\
\hline Perilaku Tepat & 37 & 61,7 \\
Perilaku Kurang & & - \\
Tepat & - & \\
Perilaku Tidak & & 38,3 \\
Tepat & 23 & \\
& & \\
\hline
\end{tabular}

Berdasarkan perilaku Ibu tentang pemberian susu formula menunjukkan hampir setengah jumlah responden dengan perilaku tidak tepat sebanyak 32 orang 
Ibu $(53,3 \%)$ yang berkunjung ke Posyandu Wilayah Kelurahan Dinoyo Kota Malang.

Perilaku Ibu tentang pemberian susu formula terkait dengan sikap merupakan gambaran suka atau tidak suka seseorang terhadap suatu objek. Sikap biasa diperoleh dari pengalaman sendiri atau pengalaman orang lain (Notoadmodjo, 2012). Shaker menyebutkan bahwa orang tua yang memberikan ASI kepada bayi mereka mempunyai sikap positif terhadap ASI dibanding dengan orang tua yang memberikan susu formula (Shaker, 2004) dan orang tua yang memberikan ASI pada bayi mereka mempunyai pengetahuan yang baik tentang keuntungan kesehatan dan kandungan gizi dari ASI. Shaker menyebutkan bahwa orang tua yang memberikan ASI kepada bayi mereka mempunyai sikap positif terhadap ASI dibanding dengan orang tua yang memberikan susu formula. Sejalan pendapat Notoatmojdo (2012) bahwa seseorang yang bersikap atau menilai sesuatu yang berkaitan dengan kesehatan, pada dasarnya mereka sudah mengetahui tujuan, manfaat, serta bahaya bagi kesehatan dirinya dan keluarganya. Hasil wawancara dalam penelitian ini diketahui jika ibu mengganggap susu formula tidak memiliki dampak negatif bagi bayi karena susu formula banyak dijual bebas bahkan di apotek. Ibu berasumsi jika susu formula berbahaya maka peredarannya akan dibatasi oleh pemerintah.

Hasil penelitian ini juga didukung pendapat Sunaryo (2005) bahwa perilaku adalah aktivitas yang timbul karena adanya stimulus dan respon yang dapat diamati secara langsung maupun tidak langsung, serta menurut pendapat Asfryati (2013) bahwa seorang ibu dalam keluarga terutama anak adalah mendidik dan menjaga anak-anaknya dari usia bayi hingga dewasa karena anak tidak jauh dari pengamatan orang tua terutama ibunya. Juga didukung pendapat Nurjanah (2016) bahwa peranan Ibu terhadap anak adalah sebagai pembimbing kehidupan di dunia ini seperti dalam wujud perilaku dalam perawatan balitanya dengan pemberian susu formula, tindakan nyata dari Ayah dan Ibu dari balita khususnya pada balita usia 6-24 bulan mulai dari cara memilih susu formula, penyiapan hingga pemberiannya. Hasil penelitian oleh Ida (2015) bahwa sebagian besar sikap Ibu mengatakan setuju (59,7\%), didasari pemberian susu formula sangat menguntungkan khususnya bagi ibu dapat bekerja dan dalam beraktivitas juga setelah disusui bayi tetap menangis maka perlu diberi susu formula serta ada hubungan faktor predisposisi, faktor pemungkin, dan faktor penguat dengan pemberian susu formula pada bayi usia 6-24 bulan $\left(\rho_{\text {value }}<0,05\right)$ dan diketahui bahwa Ibu yang memberikan susu formula lebih banyak dibandingkan Ibu yang tidak memberikan susu formula.

Hasil penelitian oleh Fitri (2013) bahwa ada hubungan yang bermakna antara pendidikan dengan perilaku pemberian susu formula bayi usia 6-24 bulan ( $\rho_{\text {value }}=0,005<0,05$ artinya Ibu yang mempunyai pendidikan tinggi memiliki kemungkinan lebih besar berperilaku yang tepat dalam memberikan susu formula dibandingkan ibu yang pendidikan rendah; ada hubungan yang bermakna antara pekerjaan dengan perilaku pemberian susu formula $\left(\rho_{\text {value }}=0,014<0,05\right)$ artinya ibu yang tidak bekerja memiliki kemungkinan 7,07 kali mengalami perilaku memberikan susu formula dibandingkan ibu yang bekerja; ada hubungan yang bermakna antara sosial ekonomi dengan perilaku pemberian susu formula $\left(\rho_{\text {value }}=0,043<0,05\right)$; dan ada hubungan yang bermakna antara pekerjaan dengan perilaku pemberian susu formula $\left(\rho_{\text {value }}=0,014<0,05\right)$ artinya Ibu yang bekerja mempunyai waktu kerja sama seperti dengan pekerjaan lainnya. Adapun waktu kerja bagi pekerja yang waktu siang 7 jam satu hari dan 40 jam satu minggu untuk 6 hari kerja dalam satu minggu, atau 8 jam satu hari dan 40 jam satu minggu. Sisa waktunya 16-18 jam dipergunakan untuk kehidupan dalam keluarga, masyarakat, tidur dan lain-lain (Desi, 2010). 
Bagi pekerja wanita, bagaimanapun juga mereka adalah ibu rumah tangga yang sulit lepas begitu saja dari lingkungan keluarga. Wanita mempunyai beban dan hambatan lebih berat dibandingkan rekan prianya. Dalam arti wanita harus lebih dulu mengatasi urusan keluarga, suami, anak, dan haal-hal yang menyangkut kebutuhan rumah tangga.

\section{Tabel 3. Status Gizi Balita Usia 6-24 Bulan}

\begin{tabular}{lcc}
\hline \multicolumn{1}{c}{ Kategori } & $\begin{array}{c}\text { Jumlah } \\
(\mathbf{n})\end{array}$ & $\begin{array}{c}\text { Prosentase } \\
(\boldsymbol{\%})\end{array}$ \\
\hline Gizi Lebih & 10 & 16,7 \\
Gizi Baik & 50 & 83,3 \\
Gizi Kurang & - & - \\
Gizi Buruk & - & - \\
\hline
\end{tabular}

Status gizi pada balita usia 6-24 bulan berdasarkan hasil penelitian ini didukung teori dari Supariasa (2010) bahwa faktor yang berpengaruh terhadap status gizi antara lain faktor langsung berupa konsumsi makan bahwa pengukuran konsumsi makan sangat penting untuk mengetahui kenyataan apa yang dimakan oleh masyarakat dan hal ini dapat berguna untuk mengukur status gizi dan menemukan faktor diet yang dapat menyebabkan malnutrisi; serta faktor tidak langsung berupa pengaruh budaya dengan sikap terhadap makanan dan pola pemberian makanan dan; faktor pola asuh keluarga bahwa pola pendidikan yang diberikan orang tua kepada anak-anaknya. Produksi pangan, dengan data yang relevan adalah penyediaan makanan keluarga, sistem pertanian, tanah, peternakan dan perikanan serta keuangan. Juga menurut Almatsier (2010) bahwa perilaku sehubungan dengan peningkatan dan pemeliharaan kesehatan (health promotion behaviour). Misalnya makan makanan yang bergizi, olah raga dan sebagainya termasuk juga perilaku pencegahan penyakit (health prevention behavior) yang merupakan respon untuk melakukan pencegahan penyakit. Status gizi adalah ekspresi dari keadaan keseimbangan dalam bentuk variabel tertentu atau dapat dikatakan bahwa status gizi merupakan indikator baik buruknya penyediaan makanan sehari-hari. Selain itu status gizi merupakan keadaaan tubuh sebagai akibat konsumsi makanan (pola konsumsi makanan) dan penggunaan zatzat gizi (Irianto, 2007).

Status gizi adalah keadaan yang diakibatkan oleh keseimbangan antara asupan zat gizi dari makanan dengan kebutuhan zat gizi yang diperlukan untuk metabolisme tubuh. Setiap individu membutuhkan asupan zat gizi yang berbeda antarindividu, hal ini tergantung pada usia orang tersebut, jenis kelamin, aktivitas tubuh dalam sehari, dan berat badan (Par'I, Holil M. dkk, 2017). Balita adalah kelompok anak usia 0-59 bulan. Pada masa ini anak memerlukan asupan zat gizi seimbang baik dari segi jumlah, maupun kualitasnya untuk mencapai berat dan tinggi badan yang optimal (Kemenkes RI, 2014).

\section{Tabel 4. Hasil Tabulasi Silang}

\begin{tabular}{|c|c|c|c|c|c|c|c|c|}
\hline \multirow{4}{*}{$\begin{array}{l}\text { Variabel } \\
\text { Perilaku } \\
\text { Ibu }\end{array}$} & \multicolumn{8}{|c|}{ Status Gizi } \\
\hline & \multirow{2}{*}{\multicolumn{2}{|c|}{$\begin{array}{c}\text { Gizi } \\
\text { Buruk }\end{array}$}} & \multirow{2}{*}{\multicolumn{2}{|c|}{$\begin{array}{c}\text { Gizi } \\
\text { Kurang }\end{array}$}} & \multirow{2}{*}{\multicolumn{2}{|c|}{$\begin{array}{l}\text { Gizi } \\
\text { Baik }\end{array}$}} & \multirow{2}{*}{\multicolumn{2}{|c|}{$\begin{array}{c}\text { Gizi } \\
\text { Lebih }\end{array}$}} \\
\hline & & & & & & & & \\
\hline & $\mathrm{N}$ & $\%$ & $\mathrm{~N}$ & $\%$ & $\mathrm{~N}$ & $\%$ & $\mathrm{~N}$ & $\%$ \\
\hline Perilaku & 0 & 0 & 0 & 0 & 27 & 45 & 10 & 16,7 \\
\hline Tepat & & & & & & & & \\
\hline Perilaku & 0 & 0 & 0 & 0 & 0 & 0 & 0 & 0 \\
\hline Kurang & & & & & & & & \\
\hline Tepat & & & & & & & & \\
\hline Perilaku & 0 & 0 & 0 & 0 & 23 & 38 & 0 & 3 \\
\hline Tidak & & & & & & & & \\
\hline Tepat & & & & & & & & \\
\hline
\end{tabular}

Hasil uji ini menunjukkan variabel perilaku Ibu tentang pemberian susu formula yang bermakna dengan status gizi balita sebesar $\rho=0,000<0,05$. Dengan 
demikian terdapat hubungan perilaku Ibu yang tepat dalam memberikan susu formula dengan gizi baik pada balita usia 6-24 bulan di di Posyandu Wilayah Kelurahan Dinoyo Kota Malang.

\section{Tabel 5. Hasil Uji Rank Spearman}

\begin{tabular}{cl}
\hline \multirow{2}{*}{ Perilaku } & \multicolumn{1}{c}{ Status Gizi } \\
\cline { 2 - 2 } Ibu & $\frac{\mathrm{r}_{\text {Hitung }}=0,516}{\rho_{\text {value }}=0,000\left(\rho_{\text {value }}<0,05\right)}$ \\
& $\mathrm{n}=60$ \\
\hline
\end{tabular}

Hasil uji korelasi Rank Spearman didapatkan nilai $\mathrm{r}_{\text {hitung }}$ $=0,516$ dengan $\rho_{\text {value }}=0,000(\rho<0,05)$ artinya terdapat hubungan perilaku Ibu tentang pemberian susu formula dengan status gizi balita usia 6-24 bulan dan juga ada hubungan positif antara perilaku Ibu tentang pemberian susu formula yang semakin tepat sehingga status gizi balita usia 6-24 bulan mengalami peningkatan status gizinya di Posyandu Wilayah Kelurahan Dinoyo Kota Malang. Hasil uji korelasi Rank Spearman juga menunjukkan rata-rata nilai variabel perilaku Ibu sebesar 72,17 dan variabel status gizi sebesar 16,51 lalu nilai $\mathrm{r}_{\text {hitung }}=0,516 \rho_{\text {value }}=0,000<0,05$ artinya ada hubungan perilaku Ibu dalam pemberian susu formula dengan status gizi balita usia 6-24, dan berarti juga ada hubungan positif antara perilaku Ibu dalam memberikan susu formula dengan status gizi balita usia 6-24 bulan yang artinya jika perilaku Ibu dalam memberikan susu formula semakin tepat maka status gizi balita usia 6-24 bulan mengalami peningkatan status gizi di Puskesmas Wilayah Kelurahan Dinoyo Kota Malang.

Perilaku Ibu yang tepat dalam pemberian susu formula bahwa perilaku kesehatan (healthy behavior) adalah respon seseorang terhadap stimulus atau objek yang berkaitan dengan sehat-sakit, penyakit, dan faktor-faktor yang mempengaruhi kesehatan seperti lingkungan, makanan, minuman, dan pelayanan kesehatan. Perilaku adalah semua aktivitas atau kegiatan seseorang, baik yang dapat diamati (observable) maupun yang tidak dapat diamati (unobservable), yang berkaitan dengan pemeliharaan dan peningkatan kesehatan. Pemeliharaan kesehatan ini mencakup mencegah atau melindungi diri dari penyakit dan masalah kesehatan lain, meningkatkan kesehatan, dan mencari penyembuhan apabila sakit atau terkena masalah kesehatan. Menurut Arini (2012) bahwa sebagian besar pengetahuan manusia diperoleh melalui mata dan telinga. Proses terbentuknya keterampilan seseorang untuk bertindak perilaku baru terutama pada orang dewasa dimulai dari aspek kognitif, obyek sehingga menimbulkan pengetahuan baru pada subjek yang selajutnya akan menimbulkan respon lebih jauh lagi berupa tindakan. Semakin cukup umur maka tingkat kematangan dan kekuatan seseorang akan lebih matang dalam berpikir dan bekerja. Ibu yang berumur kurang dari 20 tahun masih belum matang dan belum siap secara jasmani dan sosial dalam menghadapi kehamilan, persalinan, serta dalam membina bayi dalam dilahirkan.

Selanjutnya faktor-faktor yang mempengaruhi perilaku Ibu yang tepat dalam pemberian susu formula antara lain faktor usia mempengaruhi kunjungan posyandu, dari faktor usia dapat ditentukan fase-fase sebagai berikut: usia kurang dari 35 tahun adalah tergolong muda usia 35 tahun keatas tergolong tua (Hartanto, 2006). Menurut Pudjiadi (2002) bahwa susu formula adalah susu yang dibuat dari susu sapi atau susu buatan yang diubah komposisinya sehingga dapat dipakai sebagai pengganti ASI. Sedangkan menurut Ngastiyah, susu formula disebut juga dengan susu buatan, oleh karena minuman buatan ini fungsinya sebagai pengganti susu ibu (Ngastiyah, 2005). Juga kondisi sosial ekonomi adalah tingkat kemampuan seseorang untuk memenuhi kebutuhan hidup. Semakin tinggi tingkat pendapatan seseorang semakin tinggi juga pendidikan, dan semakin tinggi juga pengetahuan. Hal ini memberikan hubungan antara pemberian ASI dengan ekonomi/ penghasilan ibu dimana ibu yang mempunyai 
ekonomi rendah mempunyai peluang lebih memilih untuk memberikan ASI dibanding ibu dengan sosial ekonomi tinggi (Soekanto, 2002).

Menurut WHO, susu formula adalah susu yang sesuai dan bisa diterima sistem tubuh bayi. Susu formula yang baik tidak menimbulkan gangguan saluran cerna seperti diare, muntah atau kesulitan buang air besar. Susu formula bayi juga merupakan cairan atau bubuk dengan formula tertentu yang diberikan pada bayi. Susu formula berfungsi sebagai pengganti ASI. Susu formula memiliki peranan yang penting dalam makanan bayi karena seringkali digunakan sebagai satu-satunya sumber gizi bagi bayi. Oleh karena itu komposisi susu formula yang diperdagangkan dikontrol dengan hati-hati. Oleh FDA (Food and Drugs Association) atau BPOM Amerika mensyaratkan produk ini harus memenuhi standar ketat tertentu (Sentra Laktasi Indonesia, 2007).

Susu formula adalah cairan yang berisi zat-zat didalamnya tidak mengandung antibodi, sel darah putih, zat pembunuh bakteri, enzim, hormon dan faktor pertumbuhan (Roesli, 2008). Seseorang berpendidikan tinggi dan berpengetahuan luas akan lebih bisa menerima alasan untuk memberikan ASI eksklusif karena pola pikirnya yang lebih realistis dibandingkan yang tingkat pendidikan rendah. Kriteria pendidikan yaitu sebagai berikut: SD/sederajat, SMP/sederajat, SMA/sederajat, Perguruan Tinggi. Peningkatan sarana komunikasi dan transportasi yang memudahkan periklanan distribusi susu buatan menimbulkan tumbuhnya kesediaan menyusui dan lamanya baik di Desa dan perkotaan. Distribusi, iklan dan promosi susu buatan berlangsung terus dan bahkan meningkat titik hanya di televisi, radio dan surat kabar melainkan juga ditempat-tempat praktek swasta dan klinik-klinik kesehatan masyarakat.

Umumnya susu formula untuk bayi yang beredar dipasaran berasal dari susu sapi yang diolah dengan membawa segera susu sapi ke kamar susu untuk dilakukan penyaringan agar kuman atau kotoran yang terdapat didalamnya tidak berkesempatan untuk berkembang, setelah susu sapi dari beberapa sapi disatukan sampai menjadi air susu yang homogen maka susu sapi didinginkan dengan suhu $10-15^{\circ} \mathrm{C}$. Selama $2-$ 3 jam yang berfungsi untuk menghambat pertumbuhan bakteri sehingga susu bisa bertahan lama dan setelah proses pendinginan maka susu dimasukkan kedalam botol-botol untuk dikirim kepada konsumen. Bertambahnya pendapatan keluarga atau status ekonomi yang tinggi serta lapangan pekerjaan bagi perempuan berhubungan dengan cepatnya pemberian susu botol. Artinya mengurangi kemungkinan untuk menyusui bayi dalam waktu yang lama. Meniru teman, tetangga atau orang terkemuka yang memberikan susu botol. Persepsi masyarakat gaya hidup mewah membawa dampak menurutnya kesediaan menyusui. Bahkan adanya pandangan bagi kalangan tertentu bahwa susu botol sangat cocok buat bayi dan terbaik. Hal ini dipengaruhi oleh gaya hidup yang selalu mau meniru orang lain.

\section{KESIMPULAN}

Dari 60 responden, hampir setengah jumlah Ibu dengan balita usia 6-24 bulan yang berkunjung ke Posyandu Wilayah Kelurahan Dinoyo Kota Malang berperilaku tidak tepat, sebagian besar jumlah Ibu dengan balita usia 6-24 bulan yang berkunjung ke Posyandu Wilayah Kelurahan Dinoyo Kota Malang berstatus gizi baik, dan terdapat hubungan yang nyata antara perilaku Ibu tentang pemberian susu formula dengan berstatus gizi pada balita usia 6-24 bulan, yang berkunjung ke Posyandu Wilayah Kelurahan Dinoyo Kota Malang $\left(\rho_{\text {vakue }}=0,000\right)$.

\section{UCAPAN TERIMA KASIH}

Terimakasih kepada Posyandu Wilayah Kelurahan Dinoyo Kota Malang yang telah memberikan izin untuk melakukan penelitian terkait hubungan antara perilaku Ibu tentang pemberian susu formula dengan status gizi balita usia 6-24 bulan. 


\section{DAFTAR RUJUKAN}

Atika, N, Rini, S dan Setyowati, N. 2014. Perbedaan Pemberian ASI Eksklusif dan Susu Formula Terhadap Status Gizi Bayi Umur 7-12 Bulan di Desa Reksosari Kec. Suruh Kab. Semarang (assessed 21 Januari 2018).

Adriani \& Irawan 2012 kelebihan dan kekurangan asupan zat gizi pada balita dapat mempengaruhi kesehatannya.

Almatsier. (2010). Pola Pemberian Makan, Program Pemberian Makanan Tambahan Berupa Makanan Pengganti ASI.

Annehira. (2010). Susu Formula Banyak Dipilih Ibu yang Bekerja Sebagai Makanan Pendamping ASI Bahkan Pengganti ASI Dikarenakan Susu Formula Lebih Praktis.

Aries \& Martianto (2006) dalam Saputra \& Nurrizka (2013). Indonesia Dihadapi Dinamika Persoalan Gizi Buruk.

Arini. (2012). Mengapa Seorang Harus Menyusui. Yogyakarta: Flash Books.

Arikunto (2012) dalam (Chitah,Ratih \& Husnah, 2016). Jumlah Populasi,Subjek dan Jumlah Sampel.

Atul Singhal. (2010). Peningkatan Resiko Gizi Lebih Pada Bayi yang Diberikan Susu Formula Daripada yang Diberi ASI.

Arty. (2009). Status Gizi Sangat Penting Untuk Mengetahui Ada Tidaknya Ganguan Gizi.

Astuti. (2015). Gizi, Makanan Pokok Bagi Pertumbuhan dan Kesehatan Badan.

Asfryati. (2013). Pengertian Keluarga, Peranan Seorang Ibu Dalam Mendidik Anaknya dan Mampu Memenuhi Tugas Sebagai Ibu.

Baskoro, A. 2008. ASI Panduan Praktis Ibu Menyusui. Jakarta: Banyu Media.
Bangkes Kemenkes RI. (2019). Presentase Gizi Buruk yang Diselenggarakan oleh Kementerian Kesehatan Tahun 2017.

Cahyaningsih, D.S. (2016). Pertumbuhan Perkembangan Anak dan Remaja. Jakarta: Trans Info Media.

Dewi, N. (2016). Peningkatan Berat Badan Bayi Usia 6 Bulan Antara Bayi yang Mendapat ASI Eksklusif dan Susu Formula di Wilayah Kerja Puskesmas Kartasura (assessed 21 Januari 2018).

Desi Fitriana. (2010). Faktor-faktor yang Berhubungan Dengan Perilaku Akseptor KB dalam Memilih Alat Kontrasepsi Suntik di BPS Ida Farida Depok. Skripsi. Fakultas Kebidanan STIKIM.

Depkes RI (2006) dalam Mahaling (2013). Masalah Kurang Gizi dan Masih Menjadi Masalah Kesehatan Masyarakat Juga Dapat Menjadi Penyebab Kematian. Dintasari, dkk. (2010). Studi Komparatif Penambahan Berat Badan Bayi Umur 0-6 Bulan yang Diberi MPASI dan Tanpa Diberi MP-ASI. (assesed 20 Januari 2010).

Djoko. (2016). Kelebihan dan Kekurangan

Antropometri. Indeks BB/TB.

Djitowiyono S, Kristiyanasari W. (2010). Asuhan Keperawatan Neonatus dan Anak. Yogyakarta: Nuha Medika.

Fitri, Windy Astuty. (2013). Hubungan Prediposisi, Pendorong, Pendukung Dengan Perilaku Ibu Dalam Pemberian Susu Formula Pada Bayi. Program Studi D-IV Kebidanan Sekolah Tinggi Ilmu Kesehatan Indonesia Maju.

Gibney, MJ et al. (2009). Kandungan Dalam Makanan MP-ASI Pada Balita Umur 6 Bulan Maupun Diatas 6 Bulan atau Lebih Maupun Kurang dari 6 Bulan.

Gibson (1990), dalam Cecilia (2012). Status Gizi Adalah Keadaan Tubuh yang Merupakan Hasil Akhir dari Keseimbangan Dalam Status Gizi yang Masuk Kedalam Tubuh dan Kegunaannya. 
Guilford dalam Suherman (2003). Uji Rehabilitas dan

Rehabilitas Dengan Interprestasi Koefisien

Realibilitas.

Hartanto, Hanafi. (2006). Keluarga Berencana. Jakarta: Sinar Harapan.

Hery Susanto, Rocky Wilar, Hesti Lestari. 2015. Faktor-

faktor Yang Mempengaruhi Pemberian Susu Formula

Pada Bayi yang Dirawat di Ruang Nifas RSUP Prof.

Dr. R. D. Kandou Manado. Fakultas Kedokteran

Universitas Sam Ratulangi Manado. Jurnal e-Clinic

(eCl), Volume 3, Nomor 1, Januari-April 2015.

Husaini (2010) dalam Rahim (2011). Peran Keluarga

Terutama Ibu Dalam Mengasuh Anak Akan

Menentukan Tumbuh Kembang Anak.

Hidayat (2010). Definisi Operasional Variabel Dengan

Mengidentifikasi Variabel Secara Operasional

Berdasarkan Karakteristik yang Diamati.

Khasanah, N. (2013). ASI atau Susu Formula Ya

?.Yogyakarta: Flash Books.

Khosman 2012. Konsumsi Frekuensi Pangan Artinya

Semakin Tinggi Frekuensi Konsumsi Susu Maka

Peluang Terpenuhnya Gizi Semakin Besar.

Kementerian Kesehatan Republik Indonesia. (2016).

Profil Kesehatan Indonesia Tahun 2016. (assessed 21 Januari 2018).

Lestari 2014. Frekuensi Pemberian Susu Formula, Tingkat Kucukupan Gizi.

IDAI. 2013. Air Susu Ibu dan Perannya Dalam

Pencegahan Obesitas. (assessed 21 Januari 2018).

Indiarti, dkk. 2009. Faktor-faktor Risiko yang

Berhubungan Terhadap Kejadian Kanker Payudara

Wanita.(assesed 21 Januari 2018).

.Irianto, Djoko Pekik. (2007). Panduan Gizi Lengkap

Keluarga dan Olahragawan. Yogyakarta: Andi Yogyakarta.

Khasanah,N. (2013). ASI atau Susu Formula Ya ?.Yogyakarta: Flash Books.
Mubarak, W. I. (2009). Promosi Kesehatan Untuk Kebidanan. Jakarta: Salemba Medika.

Marimbi, H. 2016. Tumbuh Kembang, Status Gizi dan Imunisasi Dasar Pada Balita. Yogyakarta: Nuha Medika.

Maryanti D, Sujianti, Budiarti, T. 2011. Buku Ajar Neonatus \& Balita. Jakarta: Trans Info Media.

Maryunani, A. 2010. Ilmu Kesehatan Anak Dalam Kebidanan. Jakarta: Trans Info Media.

Mufida, L., Widyaningsih, T. D., \& Maligan, J. M. 2015. Prinsip Dasar Makanan Pendamping Air Susu Ibu (MP-ASI) Untuk Bayi 6-24 Bulan. Kajian Pustaka, 3(4), 1646-1651.

Maulidia, Rudy Dwi Nyoto dan Anggi Srimurdianti Sukamto. (2015). Sistem Informasi KMS (Kartu Menuju Sehat) (Studi Kasus: UPTD Puskesmas Kecamatan Pontianak Barat). Program Studi Teknik Informatika Fakultas Teknik Universitas Tanjungpura123. Jurnal Sistem dan Teknologi Informasi (JUSTIN) Vol. 1, No. 1.

Monika. (2013). Sistem Pencernaan Bayi Belum Siap Untuk Menerima Susu Formula atau Makanan Padat Lainnya.

Moos \& Suddarth. (2002), yang diadopsi oleh Elvira (2014). Kuesioner Perilaku Ibu Dengan Instrumen Penelitian Perilaku Ibu Dalam Butir-Butir Pertanyaan.

Nanda Devi Kusumaningrum, Puji Hastuti, Ayu Citra Mayasari. (2014). Hubungan Perilaku Pemberian MP-ASI Dengan Status Gizi Bayi 6-24 Bulan di Posyandu Desa Bandung Mojokerto. Fakultas Ilmu Kesehatan Universitas Muhammadiyah Lamongan. Jurnal Surya. Jurnal Media Komunikasi Ilmu Kesehatan.

Ngastiyah. (2005). Ilmu Gizi Klinis Pada Anak. Balai Penerbit FKUI Jakarta. 
Nency \& Arifin (2008) Dampak Jangka Pendek dari

Kasus Gizi Kurang dan Dampak Jangka Pendek dari Status Gizi Balita.

Niga \& Purnomo (2016). Aktivitas yang Dilakukan Ibu Dalam Pemberian Makan Pada Anak.

Nirwana, A.B. (2014). ASI \& Susu Formula. Yogyakarta: Nuha Medika.

Notoatmojo. (2012). Metodologi Penelitian Kesehatan.Jakarta: PT Rineka Cipta.

Nurmawati, Ida; Sri Achadi Nugraheni dan Apoina Kartini. (2015). Faktor Determinan Pemberian Susu Formula Pada Bayi Usia 0-6 Bulan (Studi Pada Ibu Bayi Usia 7-12 Bulan di Wilayah Puskesmas Kabupaten Demak). Fakultas Kesehatan Masyarakat Universitas Diponegoro Semarang. Jurnal Manajemen Kesehatan Indonesia Volume 03 No. 01 April 2015.

Nurfarida. (2010). Hubungan Tingkat Pengetahuan Ibu

Tentang ASI Eksklusif Dengan Pemberian Susu Formula Pada Bayi Usia 0-12 Bulan di Desa Argodadi Kecamatan Sedayu Kabupaten Bantul (assesed 21 Januari 2018).

Nurjanah. (2016). Peranan Ibu Terhadap Anak Dalam Mendidik, Membimbing Buah Hatinya Hingga Dilepas Tanggungjawabnya atau Menikah dengan Orang Lain Seorang Ibu Tetap Berperan Dalam Kehidupan Anaknya.

Nursalam. (2009). Melakukan Pengukuran Variabel. Uji Hipotesis Cross Sectional.

Pudijadi, S. (2002). Ilmu Gizi Klinis Pada Anak.Jakarta: FKUI.

Puspitawati \& Sulistyarini (2013). Faktor Penyebab Masalah Gizi.

Permenkes RI. (2010). Pengukuran Bdan Tabel Antropometri Dengan Menilai Z-Score.

Perserikatan Bangsa-bangsa (2015). Harapan Pemerintah dan Tujuan SDGS Dapat Dicapai.
Proverawati, Atikah dan Rahmawati. (2011). Kapita Selekta ASI dan Menyusui. Yogyakarta: Nuha Medika.

Riskedas Tahun 2018. (2019). Status Gizi Buruk dan Gizi Kurang di Provinsi Jawa Jimur.

Rolandi, Trifen Karolus Abani. (2020). Faktor-faktor yang Berhubungan Dengan Perilaku Pemberian Asi Eksklusif Pada Bayi Usia 6-24 Bulan di Puskesmas Camplong Kabupaten Kupang Program Studi Ners Tahap Akademik Universitas Citra Bangsa Kupang

Roesly. (2008). Susu Formula Adalah Ssus yang Sesuai dan Bisa Diterima oleh Sistem Tubuh Bayi.

Scrimshaw, et,al (1989) dalam Supiriasa (2010). Faktor yang Berpengaruh Terhadap Status Gizi.

Sentra Laktasi Indonesia. (2007). Pelatihan Konseling Menyusui. Jakarta: WHO dan UNICEF.

Supariasa. (2010). Faktor Yang Berpengaruh Terhadap Status Gizi.

Saputra \& Nurrizka. (2013). Keadaan Kurang Gizi Terutama Pada Balita Akan Mengakibatkan Terganggunya Pertumbuhan Fisik dan Kecerdasan.

Sugiyono (2016). Sampel dari Jumlah dan Karakteristik yang Dimiliki oleh Populasi.

Sulistyoningsih. 2011. Pemilihan Bahan Makanan yang Tepat Akan Melahirkan Status Gizi yang Baik.

Suririnah. 2009. Proses Pembuatan Susu Formula, Kandungan Susu Formula yang Dibutuhkan Sesuai Untuk Bayi Berdasarkan Usianya.

Susanti, R. Hasanah, O. (2014). Perbandingan Kenaikan Berat Badan BBLR yang Diberi ASI dan Susu Formula Pada Dua Minggu Pertama Perawatan (assessed 21 Januari 2018).

Sasmiati. (2017). Hubungan Konsumsi Susu Formula Dengan Status Gizi Balita di Puskesmas Piyungan Bantul Yogyakarta. Naskah Publikasi. Fakultas Ilmu Kesehatan Universitas 'Aisyiyah Yogyakarta. 
Daworis, Arling, T, dke. (2021).

Santoso \& Lies. (2008). Kemampuan Untuk Belajar dan

Bekerja Serta Sikap Akan Lebih Terbatas

Dibandingkan Dengan Anak yang Normal.

Sunaryo (2005). Bentuk-bentuk Perilaku.

Soekanto, Soejono. (2002). Sosiologi Suatu Pengantar.

Jakarta: PT. Rajagrindo Persada.

Shaker I. (2004). Infant Feeding Attitudes of Expectant Parents: Breastfeeding and Formula Feeding. Journal of Advanced Nursing 2004; Vol. 45 (3).

Tyas, B.P. (2013). Hubungan Antara Pemberian ASI Eksklusif dan ASI Non Eksklusif Dengan Pertumbuhan Berat Badan Bayi 0-6 Bulan di Desa Giripurwo Wonogiri (assesed 21 Januari 2018).

UNICEF (2012) Faktor yang Mempengaruhi Status Gizi Secara Langsung Adalah Asupan Gizi dan Keadaan Penyakit Infeksi.

Wulan Ayu K, M. Zen Rahfiludin, Siti Fatimah Pradigdo. (2017). Hubungan Perilaku Ibu Terkait MP-ASI Standar WHO Dengan Status Gizi Baduta Usia 6-23 Bulan (Studi Di Kelurahan Punggawan Kota Surakarta). Jurnal Kesehatan Masyarakat (E-Journal) Volume 5, Nomor 3, FKM Undip Semarang.
Yusuf, M. (2011). Gambaran Pemberian Susu Formula Pada Bayi Usia 7-11 Bulan di Wilayah Kerja Puskesmas Minasa UPA Makassar Tahun 2011 (assessed 21 Januari 2018). 